Article

\title{
Compound Identification and In Vitro Cytotoxicity of the Supercritical Carbon Dioxide Extract of Papaya Freeze-Dried Leaf Juice
}

\author{
Kooi-Yeong Khaw ${ }^{1,2, *}$, Paul Nicholas Shaw ${ }^{1, *} * \mathbb{C}$, Marie-Odile Parat ${ }^{1}\left(\mathbb{D}\right.$, Saurabh Pandey ${ }^{1}$ \\ and James Robert Falconer 1,*(D) \\ 1 School of Pharmacy, The University of Queensland, Brisbane, QLD 4072, Australia; \\ m.parat@pharmacy.uq.edu.au (M.-O.P.); s.pandey2@uq.edu.au (S.P.) \\ 2 Biofunctional Molecule Exploratory Research Group (BMEX) School of Pharmacy, Monash University \\ Malaysia, Jalan Lagoon Selatan, Bandar Sunway 47500, Malaysia \\ * Correspondence: khaw.kooiyeong@monash.edu (K.-Y.K.); n.shaw@uq.edu.au (P.N.S.); \\ j.falconer@uq.edu.au (J.R.F.); Tel.: +60-355146135 (K.-Y.K.); +61-733464636 (P.N.S.); +61-733461852 (J.R.F.)
}

Received: 10 May 2020; Accepted: 19 May 2020; Published: 20 May 2020

\begin{abstract}
Carica papaya leaves are used as a remedy for the management of cancer. Freeze-dried C. papaya leaf juice was extracted using a supercritical fluid extraction system. Compound identification was carried out using analytical techniques including liquid chromatography coupled to high-resolution quadrupole time-of-flight mass spectrometry (LC-QToF-MS) and gas chromatography-mass spectrometry (GC-MS). The cytotoxic activities of the $\mathrm{scCO}_{2}$ extract and its chemical constituents were determined using the 3-(4,5-dimethylthiazol-2-yl)-2,5-diphenyltetrazolium bromide (MTT) assay on squamous cell carcinoma (SCC25) and human keratinocyte (HaCaT) cell lines. The chemical constituents were quantified by QToF-MS. The supercritical carbon dioxide $\left(\mathrm{scCO}_{2}\right)$ extract of papaya freeze-dried leaf juice showed cytotoxic activity against SCC25. Three phytosterols, namely, $\beta$-sitosterol, campesterol, and stigmasterol, together with $\alpha$-tocopherol, were confirmed to be present in the $\mathrm{sCCO}_{2}$ extract. Quantitative analysis showed that $\beta$-sitosterol was the major phytosterol present followed by $\alpha$-tocopherol, campesterol, and stigmasterol. $\beta$-Sitosterol and campesterol were active against SCC25 (half maximal inhibitory concentration $\left(\mathrm{IC}_{50}\right) \approx 1 \mu \mathrm{M}$ ), while stigmasterol was less active $(\sim 33 \mu \mathrm{M})$ but was biologically more selective against SCC25. Interestingly, an equimolar mixture of phytosterols was not more effective (no synergistic effect was observed) but was more selective than the individual compounds. The compounds identified are likely accountable for at least part of the cytotoxicity and selectivity effects of C. papaya.
\end{abstract}

Keywords: supercritical fluids; mass spectroscopy; ultra-high-pressure liquid chromatography; cytotoxic compound; phytosterol; stigmasterol

\section{Introduction}

Carica papaya is a herbaceous plant indigenous to tropical Mexico, Central America, and northern South America [1]. It is widely cultivated in the tropical and subtropical countries for its nutritional edible fruit [2]. Apart from the fruit of C. papaya, the leaf is used as a food and medicine. Anecdotal evidence indicates that the leaf is used in Australia in the form of a decoction to treat cancer [3]. In other parts of the world, the decoction of the leaf is used as a tea to treat high blood pressure, diabetes, digestion disorder, and jaundice, as well as dengue fever, rheumatic complaints, and elephantoid growths [4-7].

Several chemical constituents from C. papaya were identified [7]. The leaf of papaya is reported to contain alkaloids, tocopherol, flavonoids, tannins, phytosterols, saponin, phenolic compounds, 
and chlorogenic acid [8,9]. Epidemiology studies showed that phytochemicals from plants are beneficial in reducing the risk of dementia, stroke, diabetes, cardiovascular disease, and cancers [10]. Some studies demonstrated that leaf extracts from C. papaya were selectively cytotoxic to skin cancer in vitro [11,12]. Nguyen and colleagues reported that phenoside A from papaya leaf juice was potently cytotoxic to the cancerous SCC25 cell line. However, it was also cytotoxic against the non-cancerous HaCaT cell line [12]. Active and selective anti-cancer compounds from leaf juice remain to be fully elucidated.

This research gap prompted our interest to discover the bioactive chemical constituents of C. papaya leaves with selective activity against skin cancer. Supercritical fluid extraction (SFE) offers an alternative method, whereby different chemical constituents are selectively extracted from those components yielded by conventional methods. This approach may, therefore, reduce the analytical workload in identifying chemical constituents of interest. Several analytical methods were used to identify and quantify chemical constituents from papaya leaves including LC-MS, GC-MS, and nuclear magnetic resonance (NMR) spectroscopy $[11,13,14]$. For example, linoleic and linolenic acids were identified from the ethyl acetate fraction of C. papaya leaves by GC-MS [15].

Over the course of our continuing efforts to characterize anti-cancer compounds from C. papaya, we aimed to identify bioactive chemical constituents from the $\mathrm{scCO}_{2}$ extract of C. papaya. The tentatively identified compounds were obtained commercially and compared with those present in the $\mathrm{scCO}_{2}$ extract (for their liquid chromatography retention times, accurate mass, and MS/MS fragmentations). The identified compounds were analyzed and quantified. Furthermore, the cytotoxicity of the identified active compounds alone and in combination were evaluated.

\section{Materials and Methods}

\subsection{Materials}

DL- $\alpha$-Tocopherol (purity $>96 \%$ ), stigmasterol (purity >95\%), and 3-(4,5-dimethylthiazol-2-yl)-2,5diphenyltetrazolium bromide were purchased from Sigma-Aldrich (Castle Hill, NSW, Australia). $\beta$-Sitosterol (purity $>95 \%$ ) was from Chromadex (USA) and campesterol (purity $>95 \%$ ) was from Novachem (Heidelberg West, VIC, Australia). Ethanol, HPLC-grade methanol, and HPLC-grade acetone were purchased from Merck (Darmstadt, Germany). Dulbecco's modified Eagle's medium (DMEM), DMEM/F12, trypsin, penicillin/streptomycin, and fetal bovine serum (FBS) were obtained from Invitrogen (Life Technologies, Mulgrave, VIC, Australia). Freeze-dried leaf juice was prepared from Australian C. papaya leaves (grown organically) gifted by Tropical Fruit World Pty Ltd., (Duranbah, New South Wales, Australia) according to the protocol described previously [16].

\subsection{Supercritical Fluid Extraction (SFE)}

SFE of C. papaya leaf juice was performed using a laboratory-scale extraction system. Earlier experiments determined that freeze-dried leaf juice was a better starting material in comparison with fresh leaves or freeze-dried leaves when considering both extraction yield and selective toxicity to cancer cells. The SFE system comprised a liquid carbon dioxide $\left(\mathrm{CO}_{2}\right)$ reservoir, high-pressure syringe pump (Teledyne Isco 260D), a vertical 60-mL stainless-steel (SS-316) extraction vessel (University of Nottingham), backpressure regulator, heating jacket (WatLow, USA), overhead stirrer (200 rpm) and fixed straight blade paddle, and SS precipitation chamber; details are described in previous work [16]. Glass wool (Merck, Darmstadt, Germany) was placed inside the extraction vessel and covered by a stainless-steel mesh to prevent any entrainment of the sample. We previously optimized the conditions of SFE that provided the extract exhibiting most cytotoxicity toward cancer cells [16]. The extraction was operated with the following conditions: pressure $250 \mathrm{bar}$; temperature $35{ }^{\circ} \mathrm{C}$; freeze-dried leaf juice $5 \mathrm{~g}$; extraction time $3 \mathrm{~h}$. Following completion of the extraction, the supercritical fluid $(\mathrm{scCO})_{2}$ extract was separated to the precipitation chamber via a capillary nozzle $(0.0625 \mathrm{inch} ; 1.5875 \mathrm{~mm})$ and the $\mathrm{CO}_{2}$ gas was discharged to the atmosphere. The extract was weighed and stored at $-20{ }^{\circ} \mathrm{C}$ for further analysis. The experiments were repeated three times. 


\subsection{Gas Chromatography-Mass Spectrometry}

Analysis of the $\mathrm{scCO}_{2}$ extract was carried out using a Shimadzu GCMS-TQ8040. Separation was obtained on an Rtx- $5 \mathrm{~ms}$ column ( $30 \mathrm{~m} \times 0.25 \mathrm{~mm}, 0.25 \mu \mathrm{m}$ film thickness; Restek, USA) with helium as the carrier gas at a constant linear velocity of $46.6 \mathrm{~cm} / \mathrm{s}$. The injection volume was $1 \mu \mathrm{L}$ with a split ratio of 10 . The initial column temperature was held at $160^{\circ} \mathrm{C}$ for $1 \mathrm{~min}$ and then increased to $300{ }^{\circ} \mathrm{C}$ at a rate of $10{ }^{\circ} \mathrm{C} / \mathrm{min}$. The final column temperature was maintained at $300^{\circ} \mathrm{C}$ for another $10 \mathrm{~min}$. The temperatures of the injector and the detector were $240{ }^{\circ} \mathrm{C}$ and $200{ }^{\circ} \mathrm{C}$, respectively. The interface temperature was set to $300^{\circ} \mathrm{C}$. Mass acquisition was performed in the range of $42-500 \mathrm{~m} / \mathrm{z}$ using electron impact ionization at $70 \mathrm{eV}$. The components detected in the sample were identified by performing spectral database matching against the National Institute of Standards and Technology (NIST) library (v14).

\subsection{Sample Preparation for UHPLC-QToF-MS Analysis}

The standard stock solutions of DL- $\alpha$-tocopherol, stigmasterol, $\beta$-sitosterol, and campesterol were prepared by dissolving accurately weighed standards in HPLC-grade methanol to give a concentration of $1 \mathrm{mg} / \mathrm{mL}$. Each stock solution was filtered through a $0.22-\mu \mathrm{m}$ polyvinylidene fluoride (PVDF) sterile filter (Merck Millipore, Germany) and stored in a freezer at $-20^{\circ} \mathrm{C}$ prior to analysis.

\subsection{UHPLC-QToF-MS Analysis}

The chromatography analysis of DL- $\alpha$-tocopherol and phytosterols was performed on an Agilent 1290 UHPLC system (Agilent Technologies, Santa Clara, CA, USA) equipped with an Agilent 6520 high-resolution accurate mass quadruple time of flight (QToF) mass spectrometer. Chromatographic separation was conducted by a $2.0 \times 150 \mathrm{~mm}, 100 \AA, 2.6 \mu \mathrm{m} \mathrm{C} 18$ analytical column (Phenomenex, USA). Ultra-purified MilliQ water was mobile phase A, while HPLC-grade methanol was mobile phase B. The gradient elution conditions were as follows: $50 \% \mathrm{~B}$ for the first $5 \mathrm{~min} ; 50 \% \mathrm{~B}$ increasing to $90 \%$ B from $5-40 \mathrm{~min} ; 90 \%$ B increasing to $100 \%$ B from $40-60 \mathrm{~min} ; 100 \%$ B decreasing to $50 \%$ B from 60-75 min. The sample injection volume was $5 \mu \mathrm{L}$ with the flow rate of $0.2 \mathrm{~mL} / \mathrm{min}$. Mass spectral acquisition was monitored by MassHunter software (version B.02.01 SP3 -Agilent). The operating conditions for the mass spectrometer included a scan rate of 0.8 cycles/per second with the following conditions: nebuliser pressure $30 \mathrm{psi}, \mathrm{m} / \mathrm{z}$ scan $100-1700$, drying gas flow $5.0 \mathrm{~L} / \mathrm{min}$, gas temperature $300{ }^{\circ} \mathrm{C}$, fragmenting voltage $175 \mathrm{~V}$, and skimmer voltage $65.0 \mathrm{~V}$.

\subsubsection{Calibration Curves, Linearity Ranges, Limits of Detection (LOD), and Limits of} Quantification (LOQ)

In this study, four biomarker analytes were evaluated at concentrations ranging from 1.56 to $50 \mu \mathrm{g} / \mathrm{mL}$ for the determination of the linear dynamic ranges. Each individual analyte at a fixed concentration was injected three times and the resultant peak heights obtained. Calibration curves were constructed by plotting peak heights against the analyte concentrations prepared, and the linearity of response to the four compounds was evaluated by linear regression analysis.

\subsubsection{Quantification of DL- $\alpha$-Tocopherol and Phytosterols by LC-QToF-MS}

A 5- $\mu \mathrm{L}$ volume of the sample was injected into the LC-MS system. The concentration and profile of DL- $\alpha$-tocopherol and phytosterols in the extracts were obtained using optimized LC-QToF-MS parameters. Peak identifications were performed by matching the retention times and accurate masses with the standard analytes. The sample was quantified using the external standard method.

\subsection{Sample Preparation for the Cell Viability Assay}

DL- $\alpha$-Tocopherol, campesterol, stigmasterol, and $\beta$-sitosterol were dissolved in ethanol at concentrations of $10 \mathrm{mg} / \mathrm{mL}$ or $25 \mathrm{mM}$ for the combined phytosterol assay, while the $\mathrm{scCO}_{2}$ extract 
was solubilized in ethanol at a concentration of $50 \mathrm{mg} / \mathrm{mL}$. All samples were sterile-filtered by a 0.22- $\mu \mathrm{m}$ polyvinylidene fluoride (PVDF) filter (Merck Millipore, Germany), resulting in stock solutions that were diluted with serum-free medium to the indicated final concentrations prior to performing the experiments.

\subsection{Cell Culture Conditions}

Human oral squamous cell carcinoma (SCC25) cells were obtained from ATCC ${ }^{\circledR}$ CRL-1628 ${ }^{\mathrm{TM}}$, Manassas, VA, USA. The cells were maintained in DMEM/F12 medium added with 10\% v/v heat-inactivated FBS, penicillin (100 units $/ \mathrm{mL})$, streptomycin $(100 \mu \mathrm{g} / \mathrm{mL})$, and hydrocortisone $(0.4 \mu \mathrm{g} / \mathrm{mL})$. Non-cancerous human keratinocyte (HaCaT) cells were a generous gift from Professor Fusenig. The cells were grown in DMEM containing $10 \%$ FBS, penicillin (100 units $/ \mathrm{mL})$, and streptomycin $(100 \mu \mathrm{g} / \mathrm{mL})$. All cell lines were cultured in a humidified atmosphere with $5 \% \mathrm{CO}_{2}$ at $37^{\circ} \mathrm{C}$. The cultures were passaged every third day, at which point they were approximately $70 \%-90 \%$ confluent.

\section{Cell Viability Assay}

The 3-(4,5-dimethylthiazol-2-yl)-2,5-diphenyltetrazolium bromide (MTT) assay was performed according to the method previously optimized for anticancer bioactive discovery [11,12]. In brief, 6000 cells (SCC25) per well or 3000 cells (HaCaT) were seeded in each well of a 96-well microtiter ${ }^{\mathrm{TM}}$ microplate. The cells were allowed to attach for $24 \mathrm{~h}$ prior to addition of samples. The culture medium was replaced with samples to be tested diluted in serum-free medium. The samples were incubated for $48 \mathrm{~h}$ at $37^{\circ} \mathrm{C}$, and the serum-free medium was replaced with a $0.5 \mathrm{mg} / \mathrm{mL}$ MTT solution. After a 2-h incubation, the medium was replaced with $100 \mu \mathrm{L}$ of dimethyl sulfoxide (DMSO) on an orbital shaker for $20 \mathrm{~min}$. The absorbance values were measured at $595 \mathrm{~nm}$ using an Lmark plate reader (BioRad, Hercules, California, USA). Wells containing no cells was being used as blanks whose absorbance was subtracted. Results are expressed as the percentage of viable cells with control, with untreated cells taken as $100 \%$. The half maximal inhibitory concentration $\left(\mathrm{IC}_{50}\right)$ values of the compounds were estimated using non-linear regression analysis implemented in Prism 7 (GraphPad software Inc., San Diego, CA, USA).

\subsection{Statistical Analysis}

All statistical analysis was performed using Prism 7 (GraphPad software Inc., San Diego, CA, USA). All data are presented as means \pm standard error of mean (SEM). Two-way ANOVA with a Sidak post hoc test was employed to compare the differences between the two cell lines.

\section{Results}

\subsection{Supercritical Carbon Dioxide Extraction}

Freeze-dried leaf juice of $C$. papaya was extracted using a $\mathrm{scCO}_{2}$ extraction system. The extraction yield of $\mathrm{scCO}_{2}$ freeze-dried leaf juice was 3.2\% $(n=3)$.

\subsection{Chemical Analysis of $\mathrm{scCO}_{2}$ Extract with GC-MS}

GC-MS results showed that at least 11 volatile compounds were present in the $\mathrm{scCO}_{2}$ extract of freeze-dried leaf juice of papaya (Figure A1).

The mass spectral database of these compounds was matched (>95\%) with the NIST library. Lipophilic compounds including fatty acids, vitamin E, and the phytosterols were tentatively assigned, and they are listed in Table 1 . The results showed that DL- $\alpha$-tocopherol (25.15\%) and $\beta$-sitosterol (40.96\%) were the major compounds detected, followed by campesterol (9.87\%) and stigmasterol (8.86\%). 
Table 1. Volatile compounds identified by GC-MS.

\begin{tabular}{ccccc}
\hline Peak & $\begin{array}{c}\text { Retention Time } \\
\text { (Min) }\end{array}$ & Peak Area & $\begin{array}{c}\text { a Peak Area } \\
\mathbf{( \% )}\end{array}$ & $\begin{array}{c}\text { Tentative Compound } \\
\text { Identification }\end{array}$ \\
\hline 1 & 8.673 & 863,427 & 1.71 & Linolenic acid \\
Squalene \\
2 & 13.820 & 542,784 & 1.07 & $\gamma$-Tocopherol \\
3 & 15.417 & $2,380,812$ & 4.71 & $\beta$-Sitosterol acetate \\
4 & 15.884 & 624,002 & 1.23 & DL- $\alpha$-Tocopherol \\
5 & 16.034 & $12,690,750$ & 25.15 & Campesterol \\
6 & 17.000 & $4,980,249$ & 9.87 & Stigmasterol \\
7 & 17.293 & $4,474,003$ & 8.86 & $\beta$-Sitosterol \\
8 & 17.89 & $20,663,841$ & 40.96 & $\alpha$-Amyrin \\
9 & 18.08 & $1,819,771$ & 3.60 & Brassicasterin \\
10 & 18.74 & $1,403,996$ & 2.78 & 3-Oxocholest-4-en-27-yl acetate \\
11 & 19.51 & $1,289,165$ & 2.53 &
\end{tabular}

\subsection{Compound Identification by Comparison with Authentic Standards}

Based on the results from the database searching and the tentative identification of compounds from GC-MS analysis, direct comparison of the four compounds with four commercially available standards (DL- $\alpha$-tocopherol, $\beta$-sitosterol, stigmasterol, and campesterol) with the $\mathrm{scCO}_{2}$ extract of freeze-dried leaf juice was performed using LC-MS.

Table 2 shows the comparison of the masses and retention times of the respective standards and features derived from the $\mathrm{scCO}_{2}$ extract of freeze-dried leaf juice detected in positive ion mode. All protonated phytosterols likely lost a molecule of water and, hence, the ions detected by the mass spectrometer are of the form $\left[\mathrm{M}+\mathrm{H}-\mathrm{H}_{2} \mathrm{O}\right]^{+}$. All compounds were matched to the retention times, accurate masses, and MS/MS fragmentations of the reference compounds (Figure 1a-d).
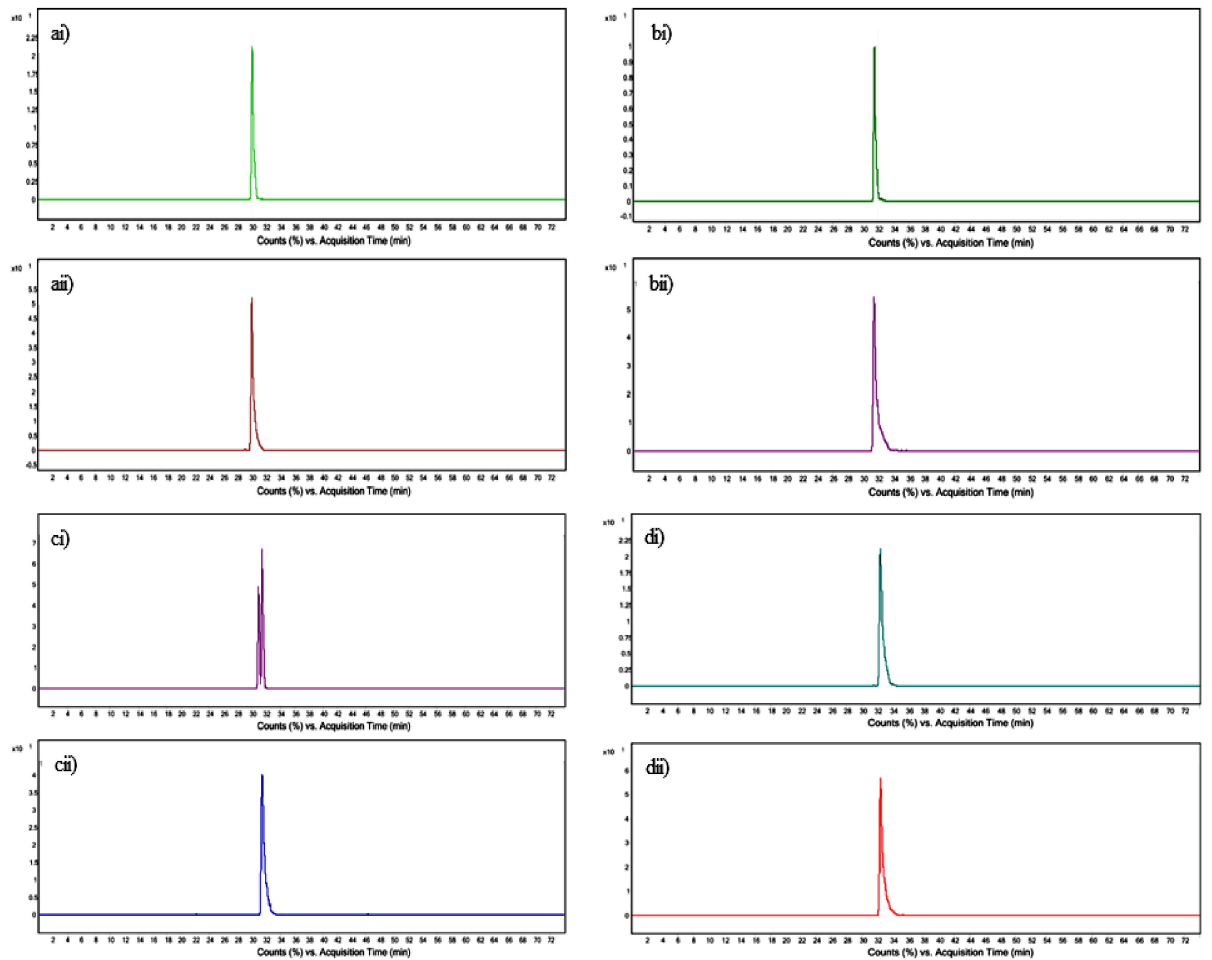

Figure 1. (ai) Extracted ion chromatogram (EIC) of $\mathrm{m} / \mathrm{z} 431.3884$ for the $\mathrm{scCO}_{2}$ extract. (aii) EIC of $\mathrm{m} / \mathrm{z}$ 431.3823 for the DL- $\alpha$-tocopherol standard; (bi) EIC of $m / z 383.3662$ for the $\mathrm{scCO}_{2}$ extract; (bii) EIC of $\mathrm{m} / \mathrm{z} 383.3683$ for the campesterol standard; (ci) EIC of $\mathrm{m} / \mathrm{z} 395.3668$ for the $\mathrm{scCO}_{2}$ extract; (cii) EIC of $\mathrm{m} / \mathrm{z}$ 395.3669 for the stigmasterol standard; (di) EIC of $\mathrm{m} / \mathrm{z}$ 397.1361for the $\mathrm{scCO}_{2}$ extract; (dii) $\mathrm{EIC}$ of $\mathrm{m} / \mathrm{z}$ 397.1347 for the $\beta$-sitosterol standard. 
Table 2. Phytochemicals determined by LC-electrospray ionization (ESI)-ToF MS in the $\mathrm{scCO}_{2}$ extract of freeze-dried leaf juice (positive mode).

\begin{tabular}{cccccccc}
\hline Standard & $\begin{array}{c}\text { Mass of } \\
\text { Standard } \\
{[\mathbf{M}+\mathbf{H}-} \\
\left.\mathbf{H}_{\mathbf{2}} \mathbf{O}\right]^{+} \mathbf{m} / \mathbf{z}\end{array}$ & $\begin{array}{c}\text { Retention } \\
\text { Time of } \\
\text { Standard } \\
(\mathbf{m i n})\end{array}$ & $\begin{array}{c}\text { Product } \\
\text { ion } \\
\text { Standard } \\
\mathbf{m} / \mathbf{z}\end{array}$ & $\begin{array}{c}\text { Mass of } \\
\text { Feature } \\
{[\mathbf{M}+\mathbf{H}-} \\
\left.\mathbf{H}_{\mathbf{2}} \mathbf{O}\right]^{+} \\
\mathbf{m} / \mathbf{z}\end{array}$ & $\begin{array}{c}\text { Retention } \\
\text { Time of } \\
\text { Feature } \\
(\mathbf{m i n})\end{array}$ & $\begin{array}{c}\text { Product } \\
\text { ion } \\
\text { of Feature } \\
\mathbf{m} / \mathbf{z}\end{array}$ & $\begin{array}{c}\text { Molecular } \\
\text { Formula }\end{array}$ \\
\hline DL- $\alpha$-Tocopherol & 431.3823 & 30.049 & 165.120 & 431.3884 & 30.043 & 165.139 & $\mathrm{C}_{29} \mathrm{H}_{50} \mathrm{O}_{2}$ \\
Campesterol & 383.3683 & 31.429 & 161.180 & 383.3662 & 31.464 & 161.187 & $\mathrm{C}_{28} \mathrm{H}_{48} \mathrm{O}$ \\
Stigmasterol & 395.3669 & 31.457 & 255.187 & 395.3668 & 31.497 & 255.220 & $\mathrm{C}_{29} \mathrm{H}_{48} \mathrm{O}$ \\
$\beta$-Sitosterol & 397.1347 & 32.407 & 161.185 & 397.1361 & 32.409 & 161.188 & $\mathrm{C}_{29} \mathrm{H}_{50} \mathrm{O}$ \\
\hline
\end{tabular}

\subsection{Quantification of Tocopherol and Phytosterols by UPLC-QToF-MS}

The responses of all compounds possessed good linearity where DL- $\alpha$-tocopherol, campesterol, and $\beta$-sitosterol were linear over the concentration range of $1.56-50 \mu \mathrm{g} / \mathrm{mL}\left(r^{2}=0.9992,0.9987\right.$, and 0.9991, respectively), and stigmasterol was linear over the range 3.12-50 $\mu \mathrm{g} / \mathrm{mL}$. The LODs were calculated using a signal-to-noise ratio of 3 . The LOD was $0.39 \mu \mathrm{g} / \mathrm{mL}$ for stigmasterol campesterol, and $\beta$-sitosterol, and $0.19 \mu \mathrm{g} / \mathrm{mL}$ for $\mathrm{DL}-\alpha$-tocopherol. The LOQs were calculated at a signal-to-noise ratio of 10 . The LOQ was $1.56 \mu \mathrm{g} / \mathrm{mL}$ for stigmasterol, campesterol, and $\beta$-sitosterol, and $0.78 \mu \mathrm{g} / \mathrm{mL}$ for DL- $\alpha$-tocopherol (Table 3).

Table 3. Linearity, limit of detection (LOD), and limit of quantification (LOQ) of tocopherol and phytosterols.

\begin{tabular}{cccccc}
\hline Compound & Calibration Curve & $\boldsymbol{R}^{2}$ & $\begin{array}{c}\text { Linear Range } \\
(\mu \mathrm{g} / \mathrm{mL})\end{array}$ & $\begin{array}{c}\text { LODs } \\
(\mu \mathrm{g} / \mathrm{mL})\end{array}$ & $\begin{array}{c}\text { LOQs } \\
(\mu \mathrm{g} / \mathrm{mL})\end{array}$ \\
\hline DL- $\alpha$-Tocopherol & $y=2668.2 x+4301.4$ & 0.9992 & $50-1.56$ & 0.19 & 0.78 \\
Stigmasterol & $y=956.46 x+2623.6$ & 0.9979 & $50-3.12$ & 0.39 & 1.56 \\
Campesterol & $y=1008.1 x+1213.6$ & 0.9987 & $50-1.56$ & 0.39 & 1.56 \\
$\beta$-Sitosterol & $y=1718.1 x+1316.6$ & 0.9991 & $50-1.56$ & 0.39 & 1.56 \\
\hline
\end{tabular}

The concentrations of tocopherol and phytosterols from C. papaya were evaluated. The content of each compound was calculated as $\mu \mathrm{g} / 100 \mathrm{mg}$ of original leaf. The concentrations of tocopherol and phytosterols were in the range of 0.33 to $1.91 \mu \mathrm{g} / 100 \mathrm{mg}$ of original leaf material. $\beta$-Sitosterol was present at the highest concentration, followed by DL- $\alpha$-tocopherol, campesterol, and stigmasterol (Table 4).

Table 4. Concentrations of tocopherol and phytosterols in Carica papaya leaves.

\begin{tabular}{ccccc}
\hline \multirow{2}{*}{ Sample } & \multicolumn{2}{c}{ Content $(\boldsymbol{\mu g} / \mathbf{1 0 0} \mathbf{~ m g} \pm$ SEM of Original Leaf) $\boldsymbol{n}=\mathbf{3}$ Independent Extractions } \\
& DL- $\alpha$-Tocopherol & Stigmasterol & Campesterol & $\beta$-Sitosterol \\
\hline $\mathrm{scCO}_{2}$ extract & $1.07 \pm 0.36$ & $0.33 \pm 0.10$ & $0.55 \pm 0.08$ & $1.91 \pm 0.45$ \\
\hline
\end{tabular}

\subsection{Cytotoxicity of $\mathrm{scCO}_{2}$ Extract and Identified Compounds}

The cytotoxic effects of $\mathrm{scCO}_{2}$ extract, DL- $\alpha$-tocopherol, stigmasterol, campesterol, and $\beta$-sitosterol were evaluated against cancerous SCC25 and non-cancerous HaCaT cell lines using the MTT assay. The concentrations used ranged from 1 to $100 \mu \mathrm{g} / \mathrm{mL}$ for the individual compounds and 30 to $500 \mu \mathrm{g} / \mathrm{mL}$ for $\mathrm{scCO}_{2}$ extract. Figures 2 and 3 show SCC25 HaCaT cell viabilities upon exposure to extracts or pure compounds. The $\mathrm{sCCO}_{2}$ extract and phytosterols, but not DL- $\alpha$-tocopherol, showed statistically significant cytotoxic effects against SCC25 and HaCaT cell lines in a dose-dependent manner. Approximately $60 \%$ of SCC 25 cells survived when exposed to a concentration of $1 \mu \mathrm{g} / \mathrm{mL}$ campesterol or $\beta$-sitosterol, while $1 \mu \mathrm{g} / \mathrm{mL}$ stigmasterol only reduced cell viability to $77.1 \%$. Approximately $60 \%$ of SCC25 cells survived after treatment with $250 \mu \mathrm{g} / \mathrm{mL}$ of the $\mathrm{scCO}_{2}$ leaf juice extract. Interestingly, when comparing the selectivity of the phytosterols at $1 \mu \mathrm{g} / \mathrm{mL}$, stigmasterol resulted in the most significant difference in viabilities between the two cell lines (13.4\% difference), whereas campesterol and 
$\beta$-sitosterol demonstrated statistically significant selectivity, but with only $3.4 \%$ and $5.6 \%$ differences, respectively, at the same concentrations. On the other hand, the $\mathrm{scCO}_{2}$ extract showed significant selectivity between the two cell lines ( $p<0.001$, two-way ANOVA) with the post hoc test comparison showing the significance at each concentration tested.

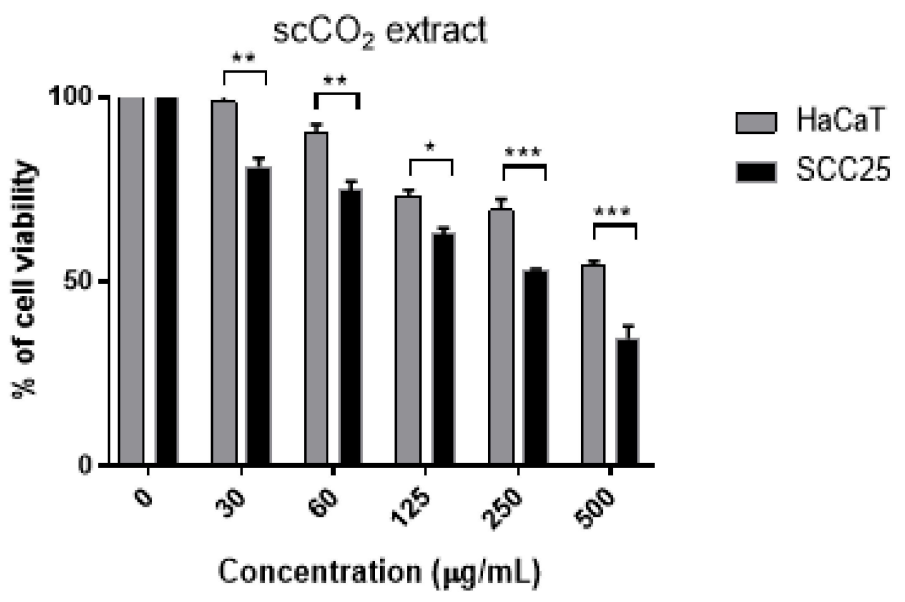

Figure 2. Effect of $\mathrm{scCO}_{2}$ extract on the viability of SCC25 and HaCaT cell lines. Results are expressed as means \pm standard error of the mean (SEM) $(n=3$ independent experiments). Statistical significance was determined by two-way ANOVA with the Sidak post hoc test, comparing the survival of HaCaT vs, $\operatorname{scc} 25\left({ }^{*} p<0.05,{ }^{* *} p<0.01,{ }^{* *} p<0.001\right)$.
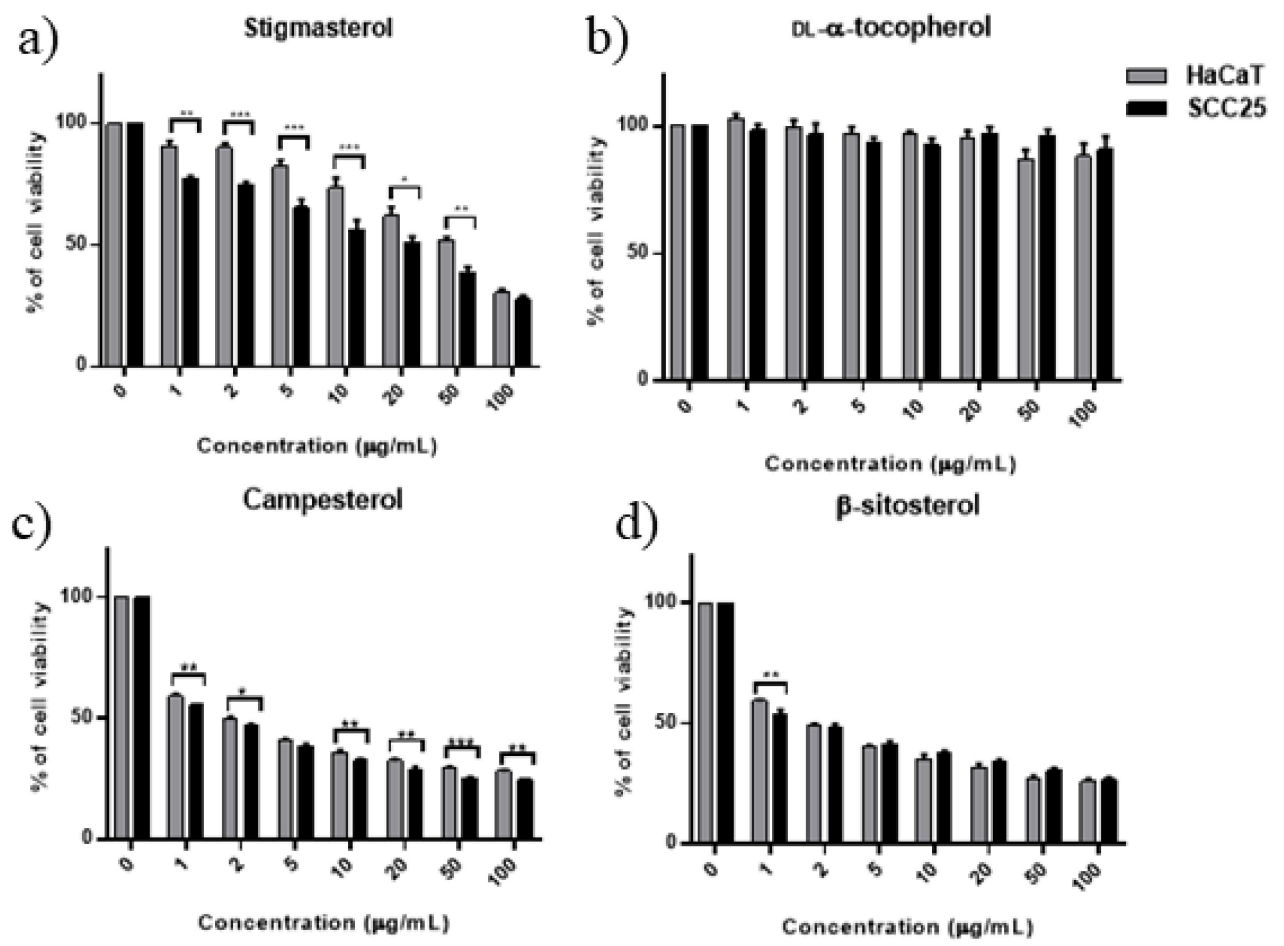

Figure 3. Effect of stigmasterol (a), DL- $\alpha$-tocopherol (b), campesterol (c), and $\beta$-sitosterol (d) on the cell viabilities of SCC25 and HaCaT cell lines. Results are expressed as means \pm SEM $(n=3$ independent experiments). Statistical significance was determined by two-way ANOVA with the Sidak post hoc test, comparing the survival of HaCaT vs. SCC25 $\left({ }^{*} p<0.05,{ }^{* *} p<0.01,{ }^{* * *} p<0.001\right)$.

Table 5 summarizes the $\mathrm{IC}_{50}$ values of the compounds and $\mathrm{scCO}_{2}$ extract toward each cell line. Campesterol was very active but not selective (had the same $\mathrm{IC}_{50}$ against SCC25 and HaCaT cells). 
Stigmasterol and $\beta$-sitosterol exhibited some selectivity toward SCC25, and stigmasterol was less toxic than the other two sterols tested. The $\mathrm{scCO}_{2}$ extract was cytotoxic against SCC25 and HaCaT cell lines at concentrations of 88.07 to $120.60 \mu \mathrm{g} / \mathrm{mL}$, respectively, confirming its selectivity.

Table 5. Half maximal inhibitory $\left(\mathrm{IC}_{50}\right)$ values of tested compounds and extract for SCC25 and HaCaT cells.

\begin{tabular}{|c|c|c|c|c|c|c|c|c|c|}
\hline \multirow{3}{*}{$\begin{array}{l}\text { Cell } \\
\text { Lines }\end{array}$} & \multicolumn{9}{|c|}{$\mathrm{IC}_{50}(95 \%$ Confidence Interval $)$} \\
\hline & \multirow{2}{*}{$\begin{array}{c}\text { DL- } \alpha- \\
\text { Tocopherol }\end{array}$} & \multicolumn{2}{|c|}{ Stigmasterol } & \multicolumn{2}{|c|}{ Campesterol } & \multicolumn{2}{|c|}{$\beta$-Sitosterol } & \multirow{2}{*}{$\begin{array}{c}\text { Equimolar } \\
\text { Sterol * } \\
\text { Mixture } \\
\mu \mathrm{M}\end{array}$} & \multirow{2}{*}{$\begin{array}{l}\mathrm{scCO}_{2} \\
\text { Extract }\end{array}$} \\
\hline & & $\mu \mathrm{g} / \mathrm{mL}$ & $\mu \mathrm{M}$ & $\mu \mathrm{g} / \mathrm{mL}$ & $\mu \mathbf{M}$ & $\mu \mathrm{g} / \mathrm{mL}$ & $\mu \mathbf{M}$ & & \\
\hline SCC25 & ND & $\begin{array}{c}14.35 \\
(11.8-18.2)\end{array}$ & 34.8 & $\begin{array}{c}0.63 \\
(0.51-0.74)\end{array}$ & 1.57 & $\begin{array}{c}0.41 \\
(0.2-0.56)\end{array}$ & 0.98 & $\begin{array}{c}5.98 \\
(3.9-8.1)\end{array}$ & $\begin{array}{c}88.07 \\
(67.9-111)\end{array}$ \\
\hline $\mathrm{HaCaT}$ & ND & $\begin{array}{c}23.41 \\
(19.1-28.7)\end{array}$ & 57.7 & $\begin{array}{c}0.63 \\
(0.53-0.73)\end{array}$ & 1.57 & $\begin{array}{c}0.78 \\
(0.65-0.91)\end{array}$ & 1.88 & $\begin{array}{c}15.60 \\
(11.2-21.6)\end{array}$ & $\begin{array}{c}120.60 \\
(95.7-152.3)\end{array}$ \\
\hline
\end{tabular}

* Equal concentrations of stigmasterol, campesterol, and $\beta$-sitosterol. ND means not detected. Parentheses show the $95 \%$ confidence interval for each compound.

\subsection{Effect of Combined Phytosterols against SCC25 and HaCaT Cell Lines}

To determine if there was a synergistic interaction between the compounds of interest, the cytotoxic effects of an equimolar mixture of stigmasterol, campesterol, and $\beta$-sitosterol on SCC25 and HaCaT cell lines were evaluated at a range of concentrations from 2.5 to $250 \mu \mathrm{M}$ (equivalent to $1-100 \mu \mathrm{g} / \mathrm{mL}$ ). In this experiment, $1 \mu \mathrm{M}$ of the mixture represents a $0.333 \mu \mathrm{M}$ concentration of each individual sterol. Figure 4 reveals the effects of the mixture against SCC25 and HaCaT cell lines. The mixture of phytosterols showed cytotoxicity with an $\mathrm{IC}_{50}$ of 5.98 and $15.60 \mu \mathrm{M}$ toward SCC25 and HaCaT cells, respectively. The selectivity of the mixture was the highest at a concentration of $5 \mu \mathrm{M}$ with $89 \%$ viable $\mathrm{HaCaT}$ and $68 \%$ viable SCC25 cells (** $p<0.01$, two-way ANOVA with the Sidak post hoc test). Two-way ANOVA analysis indicated that, overall, the treatment effect was different between the two cell lines $(p<0.0001)$.

\section{Phytosterol mixture}

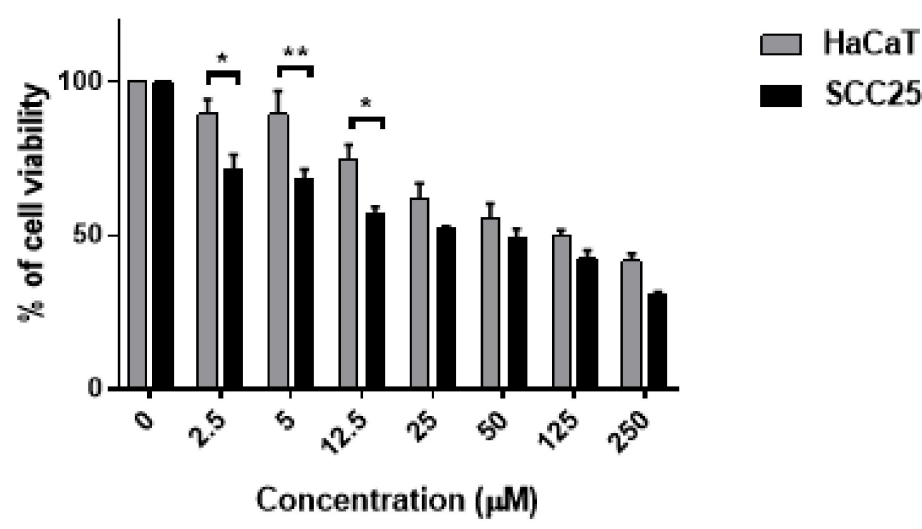

Figure 4. Effect of an equimolar mix of the three phytosterols on SCC25 and HaCaT cell lines. Statistical significance was determined by two-way ANOVA with the Sidak post hoc test, comparing the survival of HaCaT vs. SCC25 (* $\left.p<0.05,{ }^{* *} p<0.01\right)$.

The $\mathrm{IC}_{50}$ of the mixture of phytosterols indicates that the mixture of compounds is not more potent than campesterol or $\beta$-sitosterol on either cell line (Table 5), thereby excluding significant synergistic effects. It is interesting to note, however, that, with an $\mathrm{IC}_{50} \sim 3$ times lower on cancer cells than non-cancer cells, the mixture showed better selectivity than any of the individual sterols or the extract. 


\section{Discussion}

Several groups reported the potential anticancer properties of $C$. papaya leaves prepared by different extraction methods $[12,17,18]$. However, the phytochemicals responsible for cytotoxicity and selectivity are yet to be identified. An orthogonally different extraction method such as supercritical $\mathrm{CO}_{2}$ extraction method is necessary to ease the identification of compounds of interest from extracts of simplified composition [19]. There are no scientific studies in the literature which characterize the $\mathrm{scCO}_{2}$ extracts from freeze-dried leaf juice of $C$. papaya and, therefore, the present study provides the first insights into the chemotherapeutic potential of identified compounds from $\mathrm{scCO}_{2}$ extract from freeze-dried leaf juice of $C$. papaya.

Among the phytosterols confirmed to be present in the $\mathrm{scCO}_{2}$ extract in our study (stigmasterol, campesterol, and $\beta$-sitosterol), $\beta$-sitosterol was found to be the most abundant compound, followed by campesterol and stigmasterol. This quantitative result is consistent with the phytosterol biosynthesis pathway, which suggests that the most abundant end-product of plant sterol synthesis is $\beta$-sitosterol, followed by campesterol and stigmasterol [20].

The search for potential chemotherapeutic drugs involves screening for compounds selectively cytotoxic toward cancerous cells, sparing non-cancerous cells. In the present study, although campesterol and $\beta$-sitosterol were potently cytotoxic to SCC25 (with $\sim 1 \mu \mathrm{M} \mathrm{IC}{ }_{50}$ ), only stigmasterol demonstrated statistically and biologically significant selectivity over a range of concentrations. For campesterol, the selective cytotoxicity is statistically significant but of an amplitude unlikely to be of biological relevance. By comparing the structural features of all three phytosterols, a double bond in the side chain (C-22) of stigmasterol might be hypothesized to selectively affect cancer cells; however, more data are needed to confirm this claim. Another study showed that stigmasterol demonstrates chemo-preventive properties against dimethylbenz[a]anthracene-induced carcinoma in a mouse model at concentrations of $200 \mathrm{mg} / \mathrm{kg}$ and $400 \mathrm{mg} / \mathrm{kg}$ body weight [21]. This supports the further evaluation of stigmasterol as a therapeutic agent, as well as the possibility that the traditional use of papaya leaves may be derived from such activity.

While a previous study showed that phenoside A was more cytotoxic toward non-cancerous $\mathrm{HaCaT}$ cells, this study for the first time proves that the cytotoxicity and selectivity of the $C$. papaya leaf extract was due to phytosterol derivatives. However, more studies are needed to discover potential compounds that possess better selectivity toward SCC25. Some strategies including dereplication and single-compound purification from the crude extract may lead to fruitful outcomes. The scaffold of stigmasterol is for medicinal chemists to investigate its structural activity relationship and selectivity. Some of the successful cases for semi-synthetic compounds including dihydroartemisinin (arteminisin analogue) are used together with holotranferrin to treat breast cancer [22]. Interestingly, the combination of sterols demonstrated greater selectivity against SCC25 than individual sterols. This study paves the way for further in vivo study for future chemotherapy purposes and important clinical implications.

A synergistic effect is the result of the interaction of multiple agents exerting a greater effect than the total of their individual effects [23]. For example, a mixture of berberine and evodiamine demonstrated greater inhibition of the human hepatocellular carcinoma cells SMMC-7221 than single treatment by berberine or evodiamine [24]. We evaluated the possibility that the three most abundant sterols could act synergistically in selectively impairing cancer cell viability. The results suggest that no benefit results from combining equimolar concentrations of $\beta$-sitosterol, campesterol, and stigmasterol in terms of half maximal effective concentration $\left(\mathrm{EC}_{50}\right)$. However, it is interesting to note that the mixture showed better selectivity than each compound applied individually. A study by Csupor-Löffler and co-workers reported that the mixture of $\beta$-sitosterol plus stigmasterol (at an unknown ratio) from the roots of Conyza canadensis [22] was five times more cytotoxic against skin carcinoma (A431) cells than non-cancerous human fetal fibroblasts (MRC-5). The $\mathrm{IC}_{50}$ values of each individual compound against A431 and MRC-5 were not determined. 


\section{Conclusions}

In this study, four compounds from $\mathrm{scCO}_{2}$ freeze-dried leaf juice extract were identified by UPLC-QToF-MS-based chemometric and GC-MS analysis. Phytosterols were reported for the first time from papaya freeze-dried leaf juice for their cytotoxic activities against skin cancer. Stigmasterol was selective toward cancerous SCC 25 cells in comparison to non-cancerous HaCaT cells. $\beta$-Sitosterol was found to be the most abundant, followed by campesterol and stigmasterol. The present study provides evidence for further studies on the mechanism of action and in vivo efficacy of papaya leaf extracts in skin cancer.

Author Contributions: J.R.F., M.-O.P., P.N.S., and K.-Y.K. conceptualized the study; K.-Y.K. performed the experiments, analyzed the data, and wrote the manuscript; J.R.F., M.-O.P., S.P., and P.N.S. critically reviewed the manuscript. All authors have read and agreed to the published version of the manuscript.

Funding: This research was not funded.

Acknowledgments: We wish to thank Tropical Fruit World Pty Ltd., 29 Duranbah Road, Duranbah, NSW 2487 for providing fresh papaya leaves (website: tropicalfruitworld.com.au). We would like to thank Elvis Chua for his research contribution toward the GC-MS analysis.

Conflicts of Interest: The authors declare no conflicts of interest.

\section{Appendix A}

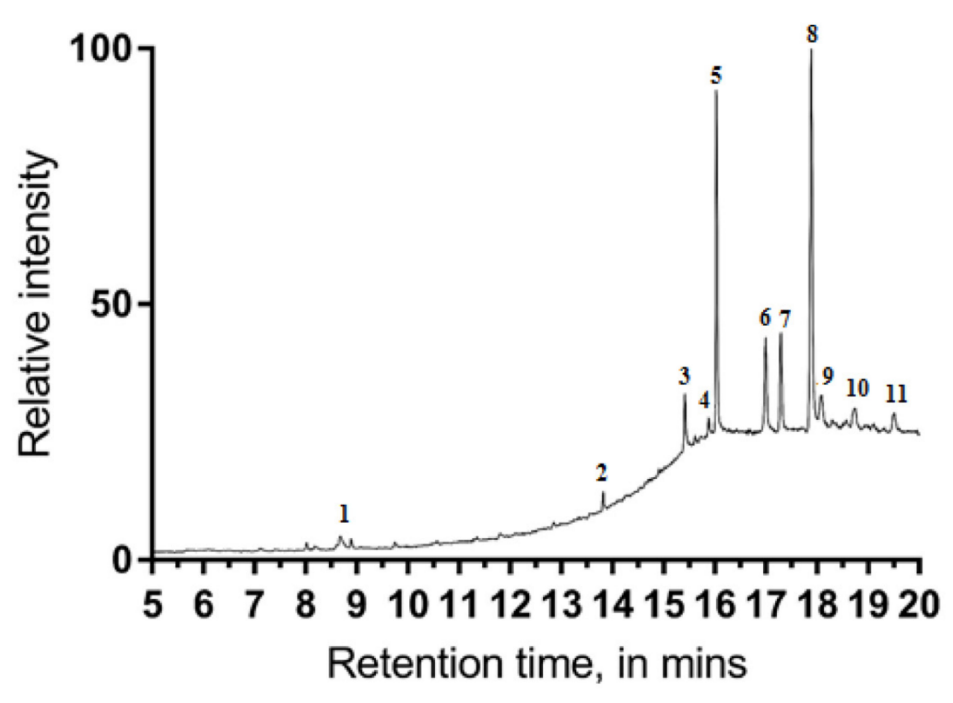

Figure A1. GC-MS analysis of $\mathrm{scCO}_{2}$ extract.

\section{References}

1. Antunes Carvalho, F.; Renner, S.S. A dated phylogeny of the papaya family (Caricaceae) reveals the crop's closest relatives and the family's biogeographic history. Mol. Phylogenet. Evol. 2012, 65, 46-53. [CrossRef] [PubMed]

2. O'Hare, T.J.; Williams, D.J. Papaya as a Medicinal Plant. In Genetics and Genomics of Papaya; Ming, R., Moore, P.H., Eds.; Springer: New York, NY, USA, 2014; pp. 391-407. [CrossRef]

3. Nguyen, T.T.T.; Shaw, P.N.; Parat, M.-O.; Hewavitharana, A.K. Anticancer activity of Carica papaya: A review. Mol. Nutr. Food Res. 2013, 57, 153-164. [CrossRef] [PubMed]

4. Ahmad, N.; Fazal, H.; Ayaz, M.; Abbasi, B.H.; Mohammad, I.; Fazal, L. Dengue fever treatment with Carica papaya leaves extracts. Asian Pac. J. Trop. Biomed. 2011, 1, 330-333. [CrossRef]

5. Gunjan, M.; Karna, L.; Dayalan, K.; Sasigaran, P. A review and search of phytomedicine used by traditional people in Malaysia (Ipoh, Perak). Int. J. Phytoterapy Res. 2012, 2, 26-41.

6. Kapoor, S.; Saraf, S. Topical herbal therapies an alternative and complementary choice to combat acne. Res. J. Med. Plant 2011, 5, 650-669. [CrossRef] 
7. Lim, T.K. Carica papaya, Edible Medicinal and Non-Medicinal Plants: Volume 1, Fruits; Springer: Dordrecht, The Netherlands, 2012; pp. 693-717. [CrossRef]

8. Pandey, S.; Cabot, P.J.; Shaw, P.N.; Hewavitharana, A.K. Anti-inflammatory and immunomodulatory properties of Carica papaya. J. Immunotoxicol. 2016, 13, 590-602. [CrossRef]

9. Vij, T.; Prashar, Y. A review on medicinal properties of Carica papaya Linn. Asian Pac. J. Trop. Dis. 2015, 5, 1-6. [CrossRef]

10. Boeing, H.; Bechthold, A.; Bub, A.; Ellinger, S.; Haller, D.; Kroke, A.; Leschik-Bonnet, E.; Müller, M.J.; Oberritter, H.; Schulze, M.; et al. Critical review: Vegetables and fruit in the prevention of chronic diseases. Eur. J. Nutr. 2012, 51, 637-663. [CrossRef]

11. Nguyen, T.; Parat, M.-O.; Hodson, M.; Pan, J.; Shaw, P.; Hewavitharana, A. Chemical Characterization and in vitro Cytotoxicity on Squamous Cell Carcinoma Cells of Carica Papaya Leaf Extracts. Toxins 2016, 8, 7. [CrossRef]

12. Nguyen, T.T.; Parat, M.-O.; Shaw, P.N.; Hewavitharana, A.K.; Hodson, M.P. Traditional Aboriginal Preparation Alters the Chemical Profile of Carica papaya Leaves and Impacts on Cytotoxicity towards Human Squamous Cell Carcinoma. PLoS ONE 2016, 11, e0147956. [CrossRef]

13. Gogna, N.; Hamid, N.; Dorai, K. Metabolomic profiling of the phytomedicinal constituents of Carica papaya L. leaves and seeds by ${ }^{1} \mathrm{H}$ NMR spectroscopy and multivariate statistical analysis. J. Pharm. Biomed. Anal. 2015, 115, 74-85. [CrossRef] [PubMed]

14. Lieb, V.M.; Esquivel, P.; Cubero Castillo, E.; Carle, R.; Steingass, C.B. GC-MS profiling, descriptive sensory analysis, and consumer acceptance of Costa Rican papaya (Carica papaya L.) fruit purees. Food Chem. 2018, 248, 238-246. [CrossRef] [PubMed]

15. Melariri, P.; Campbell, W.; Etusim, P.; Smith, P. Antiplasmodial Properties and Bioassay-Guided Fractionation of Ethyl Acetate Extracts from Carica papaya Leaves. J. Parasitol. Res. 2011, 2011, 104954. [CrossRef] [PubMed]

16. Khaw, K.-Y.; Parat, M.-O.; Shaw, P.N.; Nguyen, T.T.T.; Pandey, S.; Thurecht, K.J.; Falconer, J.R. Factorial design-assisted supercritical carbon-dioxide extraction of cytotoxic active principles from Carica papaya leaf juice. Sci. Rep. 2019, 9, 1716. [CrossRef] [PubMed]

17. Pandey, S.; Walpole, C.; Cabot, P.J.; Shaw, P.N.; Batra, J.; Hewavitharana, A.K. Selective anti-proliferative activities of Carica papaya leaf juice extracts against prostate cancer. Biomed. Pharmacother. 2017, 89, 515-523. [CrossRef]

18. Otsuki, N.; Dang, N.H.; Kumagai, E.; Kondo, A.; Iwata, S.; Morimoto, C. Aqueous extract of Carica papaya leaves exhibits anti-tumor activity and immunomodulatory effects. J. Ethnopharmacol. 2010, 127, 760-767. [CrossRef]

19. Khaw, K.-Y.; Parat, M.-O.; Shaw, P.N.; Falconer, J.R. Solvent Supercritical Fluid Technologies to Extract Bioactive Compounds from Natural Sources: A Review. Molecules 2017, 22, 1186. [CrossRef]

20. Hartmann, M.-A. 5 Sterol metabolism and functions in higher plants. In Lipid Metabolism and Membrane Biogenesis; Daum, G., Ed.; Springer: Berlin/Heidelberg, Germany, 2004; pp. 183-211. [CrossRef]

21. Ali, H.; Dixit, S.; Ali, D.; Alqahtani, S.M.; Alkahtani, S.; Alarifi, S. Isolation and evaluation of anticancer efficacy of stigmasterol in a mouse model of DMBA-induced skin carcinoma. Drug Des. Dev. Ther. 2015, 9, 2793-2800. [CrossRef]

22. Csupor-Löffler, B.; Hajdú, Z.; Zupkó, I.; Molnár, J.; Forgo, P.; Vasas, A.; Kele, Z.; Hohmann, J. Antiproliferative Constituents of the Roots of Conyza canadensis. Planta Med. 2011, 77, 1183-1188. [CrossRef]

23. van Vuuren, S.; Viljoen, A. Plant-Based Antimicrobial Studies-Methods and Approaches to Study the Interaction between Natural Products. Planta Med. 2011, 77, 1168-1182. [CrossRef]

24. Wang, X.N.; Han, X.; Xu, L.N.; Yin, L.H.; Xu, Y.W.; Qi, Y.; Peng, J.Y. Enhancement of apoptosis of human hepatocellular carcinoma SMMC-7721 cells through synergy of berberine and evodiamine. Phytomedicine 2008, 15, 1062-1068. [CrossRef] [PubMed]

(C) 2020 by the authors. Licensee MDPI, Basel, Switzerland. This article is an open access article distributed under the terms and conditions of the Creative Commons Attribution (CC BY) license (http://creativecommons.org/licenses/by/4.0/). 